\title{
Urea uptake kinetics of a midsummer planktonic community on the SW coast of Finland
}

\author{
Timo Tamminen ${ }^{1, *}$, Andreas Irmisch ${ }^{2}$ \\ ${ }^{1}$ Tvärminne Zoological Station, FIN-10900 Hanko, Finland \\ ${ }^{2}$ Forschungszentrum Jülich GmbH, D-18112 Rostock, Germany
}

\begin{abstract}
Urea uptake of the planktonic community was studied in a series of experiments on the SW coast of Finland, the Baltic Sea, in midsummer. Uptake was measured with ${ }^{14} \mathrm{C}$-urea incubations where respired ${ }^{14} \mathrm{CO}_{2}$ was found to represent 98 to $99 \%$ of total uptake. Uptake kinetics were characterized by high affinity for urea $\left(0.97\right.$ to $\left.1.84 \mu \mathrm{g} \mathrm{N} \mathrm{l}^{-1}\right)$, fast turnover rates $\left(29\right.$ to $\left.99 \% \mathrm{~h}^{-1}\right)$ and moder-

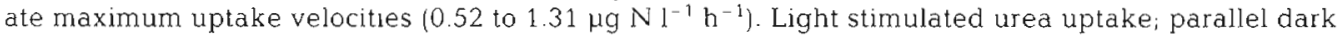
incubations usually yielded uptakes 60 to $80 \%$ of those in the light. No surge uptake of urea was observed, as all kinetic parameters remained constant in a short-term time series experiment. Sizefractionation studies and light/dark incubations indicated that phytoplankton dominated urea uptake. The time course of urea depletion in an enrichment experiment followed the diel primary production pattern, and the depletion rate was of the same order as the ammonium depletion rate. Inorganic nitrogen additions (ammonium, nitrate) did not produce immediate inhibitions of urea uptake, but with a time lag of 1 night, ammonium inhibition was observed. Phosphate addition stimulated urea uptake. Evidence on stimulated bacterioplankton uptake of urea was found the next night after organic carbon source addition. Alternative nitrogen sources $\left(\mathrm{NO}_{3}, \mathrm{NH}_{4}\right.$, urea) were utilized mainly according to their availability. Urea proved to be an important nitrogen source for phytoplankton during the regenerated phase of plankton succession.
\end{abstract}

KEY WORDS: Urea - Uptake kinetics Phytoplankton - Bacterioplankton Nitrogen sources Preference. Inhibition Baltic Sea

\section{INTRODUCTION}

Studies of nitrogenous nutrition of the planktonic community have shown the importance of organic nitrogen sources, especially urea and amino acids. In culture studies, several algal species have been shown capable of utilizing urea as their sole nitrogen source (e.g. Antia et al. 1975).

During the regenerated phase of plankton succession, urea has usually been reported as the most favoured nitrogen source after ammonium for the plankton community in offshore (Eppley et al. 1971. 1973, 1977, Kanda et al. 1985), coastal (McCarthy 1972, Harvey \& Caperon 1976, McCarthy et al. 1977. Paasche \& Kristiansen 1982, Kristiansen 1983, Furnas et al. 1986, Sahlsten et al. 1988) and freshwater

•E-mail: timo.tamminen@vyh.fi
(McCarthy et al. 1982, Mitamura \& Saijo 1986) environments. On several occasions, urea equalled or exceeded $\mathrm{NH}_{4}$ in preference during the regenerated production phase. In size-fractionation experiments accompanied by specific inhibitors, Wheeler \& Kirchman (1986) found that picoplankton $(<1 \mu \mathrm{m})$, representing both bacterioplankton and procaryotic and eucaryotic phototrophs, did not take up urea.

In the Baltic Sea, virtually nothing is known of the role of urea in planktonic nutrition. In this paper we summarize the results from a series of experiments on urea uptake, including assimilation kinetics, time course experiments, size-fractionation studies, and stimulation or inhibition by inorganic and organic nutrient additions. The data are based on measurements of ${ }^{14} \mathrm{C}$-urea uptake, chemical urea analyses and comparisons with parallel chlorophyll analyses and primary and bacterial productivity measurements. 


\section{MATERIAL AND METHODS}

Sampling and experimental conditions. The water for all experiments originated from the surface layer of a pelagic sampling station outside the outer archipelago line, some $6 \mathrm{~km}$ off the Tvärminne Zoological Station, at the entrance to the Gulf of Finland, the Baltic Sea. The experimental period covered 2 wk (21 June to 1 July 1988) of the midsummer stage of the planktonic succession, characterized by exceptionally calm and warm weather, which caused the surface temperature to rise from 16 to $22.5^{\circ} \mathrm{C}$ during the period

Experiments were performed at in situ temperature in a thermostated water bath which followed the natural irradiation cycle as it was situated outdoors, sheltered from direct sunlight. Irradiation level was ca $13 \%$ of surface irradiance, corresponding to light levels of 3 to $4 \mathrm{~m}$ at the sampling location.

Prefiltrations in the experiments were performed by filtering water through polycarbonate filters (Nuclepore 3 and $0.8 \mu \mathrm{m}$ ) or filters cut from nylon plankton. net (10 and $20 \mu \mathrm{m}$ mesh size). Filter diameter was $50 \mathrm{~mm}$ and no additional vacuum was applied in prefiltrations.

Chemical analyses. Chemical analyses of dissolved nutrients (urea, ammonium, phosphate) were performed manually in duplicate according to the methods presented in Grasshoff (1976). Particulate organic nitrogen was determined after filtering $(<100 \mathrm{~mm} \mathrm{Hg})$ the samples onto acid-washed and precombusted $\left(4 \mathrm{~h}\right.$ at $500^{\circ} \mathrm{C}$ ) glass-fibre filters (Whatman GF/F). In organic nitrogen analyses, the measurement of nitrate after sample oxidation according to Grasshoff (1976) was performed by Flow Injection Analysis (FIA). The FIA procedure was slightly modified after Johnson \& Petty (1983), and a Tecator 5020 FIAstar apparatus was used for the analyses. Glassware for organic $\mathrm{N}$ filtrations was acid-washed and precombusted. Chlorophyll a (chl a) was measured fluorometrically (Sequoia-Turner 450) after sonication and ethanol extraction ( $24 \mathrm{~h}$ at room temperature) of samples filtered onto glass-fibre filters (Whatman GF/F)

Urea uptake. Urea uptake was measured after incubations with ${ }^{14} \mathrm{C}$-urea (CFA.41. Amersham International, Buckinghamshire, UK; specific activity $56 \mathrm{mCi}$ $\mathrm{mmol}^{-1}$ ), in closed incubation bottles with a glass cup installed in a rubber stopper for the collection of respired ${ }^{14} \mathrm{CO}_{2}$ (Kuparinen \& Uusi-Rauva 1.980). Incubations were terminated by injecting $200 \mu \mathrm{l}$ of $4.5 \mathrm{M}$ $\mathrm{H}_{2} \mathrm{SO}_{4}$ into the $10 \mathrm{ml}$ sample through the rubber stopper, whereafter $300 \mu$ of ethanolamine was similarly injected into the glass cup. After $24 \mathrm{~h}$, incubation bottles were opened and the glass cup was carefully removed into a scintillation vial for the measurement of respired ${ }^{14} \mathrm{CO}_{2}$.
A scintillation cocktail of $5 \mathrm{ml}$ ethanol and $10 \mathrm{ml}$ PCS (Amersham International) was added to the vial, and the radioactivities were measured with a LKB-Wallac 1219 RackBeta liquid scintillation counter with the external channel ratio method. When particulate ${ }^{14} \mathrm{C}$ was also measured, the $10 \mathrm{ml}$ samples were filtered $(<100 \mathrm{~mm} \mathrm{Hg}$ ) onto $0.2 \mu \mathrm{m}$ membrane filters (Sartorius) after the removal of the respiration cup. A $10 \mathrm{ml}$ volume of PCS was added on the filters placed in scintillation vials, and radioactivities were measured as above.

A blank sample was prepared by adding $50 \mu \mathrm{l}$ of $38 \%$ formaldehyde in the $10 \mathrm{ml}$ sample before the addition of radioactivity, after which the blank was treated similarly to the samples. Duplicate incubations with a blank were used routinely for all incubations, including the different added concentrations in kinetic studies.

Other rate measurements. Primary productivity was measured with the ${ }^{14} \mathrm{C}$ method (Steemann Nielsen 1952, the modification presented by Niemi et al. 1983) as apparent net productivity (particulate + dissolved organic ${ }^{14} \mathrm{C}$ ), after incubations of $20 \mathrm{ml}$ samples with $2 \mu \mathrm{Ci}$ addition of $\mathrm{NaH}^{14} \mathrm{CO}_{3}$ (CFA.3, Amersham International). Incubation time was ca $2 \mathrm{~h}$, duplicates with a dark blank were incubated for each sample, and incubations were terminated by the addition of $38 \%$ formaldehyde ( $100 \mu \mathrm{l}$ per $20 \mathrm{ml}$ sample). A $4 \mathrm{ml}$ subsample was acidified with $100 \mu \mathrm{l}$ of $1 \mathrm{~N} \mathrm{HCl}$, and after $24 \mathrm{~h}, 7 \mathrm{ml}$ of PCS was added and radioactivities were counted as above.

Bacterial productivity was measured with the ${ }^{3} \mathrm{H}$ thymidine method (Fuhrman \& Azam 1980, 1982). ${ }^{3} \mathrm{H}$ thymidine (TRK.418, Amersham International) was added to $20 \mathrm{ml}$ samples in final concentration of $10 \mathrm{nM}$. A blank was prepared by adding $100 \mu$ of $38 \%$ formaldehyde into a $20 \mathrm{ml}$ subsample, and duplicates with a blank were incubated for each sample. Incubation time was approximately $2 \mathrm{~h}$, and incubations were terminated by the addition of formaldehyde. After icecold TCA extraction, samples were filtered onto $0.2 \mu \mathrm{m}$ membrane filters (Sartorius). Radioactivities of ${ }^{3} \mathrm{H}$ samples were counted similarly to particulate ${ }^{14} \mathrm{C}$ samples, presented above

Experiments. A time series of urea uptake (both particulate and respired ${ }^{14} \mathrm{C}$ ) was measured to define appropriate incubation times for further experiments. The urea addition was $2.3 \mu \mathrm{g} \mathrm{N} \mathrm{^{-1 }}$, and sampling times were from 0.5 to $12 \mathrm{~h}$. After $4 \mathrm{~h}$, uptake started to devi. ate significantly from linearity over time, as over $50 \%$ of the added radioactivity had been taken up. Therefore, incubation times of $2 \mathrm{~h}$ were selected for next experiments, but after urea turnover rates started to increase during the experimental period, incubation times were shortened, down to $30 \mathrm{~min}$ at the end of the period. 
Measurements of uptake kinetics of urea were performed with $4{ }^{14} \mathrm{C}$-urea addition concentrations between 0.05 and $22.6 \mu \mathrm{g} \mathrm{N}{ }^{-1}$. On each addition level, duplicate incubations with a blank were used. Uptake followed closely Michaelis-Menten kinetics, and the kinetic parameters describing urea uptake were calculated with a linear transformation (Wright \& Hobbie 1966).

In the first experiment on uptake kinetics, the $K+S_{n}$ value, which describes the affinity of the community for the substrate, was $1.75 \mu \mathrm{g} \mathrm{N}{ }^{-1}$. It has been shown (Kuparinen et al. 1984) that this parameter can be used to estimate appropriate concentrations for the determination of natural turnover rate $1 / T$ (or turnover time $T$ ) and maximum uptake rate $\left(V_{\text {max }}\right)$ with single concentration assays, these concentrations being approximately 0.1 and 10 times the $K+S_{n}$ value, respectively.

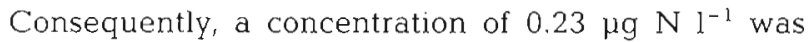
chosen for the experiments to determine the turnover rate of urea. The turnover rate $(1 / T)$ was calculated with the equation $[c /(C t)] \times 100$, where $c$ is measured radioactivity, $C$ is added radioactivity, and $t$ is incubation time, the formula yielding the turnover rate as $\% \mathrm{~h}^{-1}$.

The experimental designs for enrichment experiments are presented in Tables 1 to 3 .

In Expt 1 (Table 1), incubations started immediately after prefractionations and nutrient additions to 1 ? experimental units (22 June, around noon). Urea turnover rate in the light and in the dark was measured from all experimental units. Primary productivity was measured from the units with no or inorganic nutrient additions ( 1 to 9 ), bacterial productivity from the units with no or organic $\mathrm{C}$ (glucose) additions (1 to 3, 10 to 12) After $12 \mathrm{~h}$, at midnight, urea turnover rate and

Table 1. Design for the experiment on the immediate effects of ammonium, nitrate and glucose addition on urea turnover rate, primary productivity and bacterial productivity in differ-

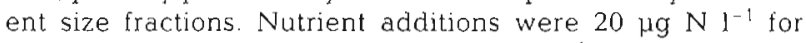
ammonium and nitrate, and $50 \mu \mathrm{g} \mathrm{N}^{-1}$ for glucose

\begin{tabular}{|rcc|}
\hline Unit & Addition & Prefractionation $(\mu \mathrm{m})$ \\
\hline 1 & - & - \\
2 & - & 20 \\
3 & - & 0.8 \\
4 & $\mathrm{NH}_{4}$ & - \\
5 & $\mathrm{NH}_{4}$ & 20 \\
6 & $\mathrm{NH}_{4}$ & 0.8 \\
7 & $\mathrm{NO}_{3}$ & - \\
8 & $\mathrm{NO}_{3}$ & 20 \\
9 & $\mathrm{NO}_{3}$ & 0.8 \\
10 & Glucose & - \\
11 & Glucose & 20 \\
12 & Glucose & 0.8 \\
\hline
\end{tabular}

Table 2. Design for the experiment on the delayed effects of ammonium, phosphate and glucose addition on urea turnover rate, primary productivity, bacterial productivity and chl a. Size fractionations were preformed from Units $1,4,5$ and 8

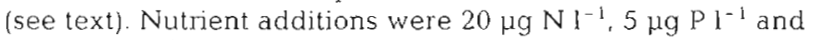
$50 \mu g \mathrm{C}^{-1}$ + and - indicate 'added' and 'not added' respectively

\begin{tabular}{|cccc|}
\hline Unit & $\mathrm{NH}_{4}$ & $\mathrm{PO}_{4}$ & Glucose \\
\hline 1 & - & - & - \\
2 & + & - & - \\
3 & - & + & - \\
4 & + & + & - \\
5 & - & - & + \\
6 & + & - & + \\
7 & - & + & + \\
8 & + & + & + \\
\hline
\end{tabular}

bacterial productivity were measured from the control and glucose addition units.

In Expt 2 (Table 2), nutrients were added into 11 experimental units in the late afternoon ( $27 \mathrm{June}$ ), and incubations for urea turnover rate, primary productivity and bacterial productivity measurements were started the next day, at noon, when chl a was also measured. Prefractionations were performed for samples from Units 1, 4, 5 and 8, immediately before the start of the incubations. Prefractionations were 20, 10, 3 and $0.8 \mu \mathrm{m}$ for urea turnover rate and primary productivity, and 3 and $0.8 \mu \mathrm{m}$ for bacterial productivity.

In Expt 3 (Table 3), urea turnover rate was measured approximately $24 \mathrm{~h}$ after nutrient additions into $2 \mathrm{l}$ experimental units, which took place 30 June at noon.

In Expt 4, depletion rate of nonlabelled urea was calculated after addition of urea $\left(20 \mu \mathrm{g} \mathrm{N} \mathrm{I}^{-1}\right)$ into a $6 \mathrm{l}$ sample in a 81 polycarbonate bottle. Both this sample and a control without urea addition were prefiltered through $20 \mu \mathrm{m}$ to remove larger zooplankton. Urea-N, ammonium- $N$ and particulate organic $N$ were assayed from the samples over $39 \mathrm{~h}$ after the addition of urea late at night, 28 June. Urea depletion rate was calcu-

Table 3. Design for the experiment on the delayed effects of nitrate, ammonium and phosphate on urea turnover rate.

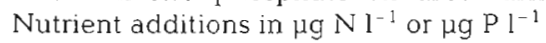

\begin{tabular}{|ccrc|}
\hline Unit & $\mathrm{NO}_{3}$ & $\mathrm{NH}_{4}$ & $\mathrm{PO}_{4}$ \\
\hline 1 & - & - & - \\
2 & 50 & - & - \\
3 & - & 5 & - \\
4 & - & 20 & - \\
5 & - & 50 & - \\
6 & - & 100 & - \\
7 & - & 50 & 20 \\
\hline
\end{tabular}


lated as the difference between successive urea analyses, expressed per hour

The depletion rates for $\mathrm{NH}_{4}$ and $\mathrm{NO}_{3}$ in Expts 1 and 3 were calculated similarly to the urea depletion rate

\section{RESULTS}

\section{Respiration percentage of ${ }^{14} \mathrm{C}$-urea}

In several experiments, both particulate and respired ${ }^{14} \mathrm{C}$ was measured after urea uptake incubations. The percentage of ${ }^{14} \mathrm{CO}_{2}$ was consistently 98 to $99 \%$ of total uptake $(\bar{X}=99.1 \%, \mathrm{SD}=0.7, \mathrm{n}=76)$, and the ratio remained the same in the light and in the dark, during a time series experiment, as well as with different added concentrations of urea. Therefore, in most enrichment experiments only respired ${ }^{14} \mathrm{CO}_{2}$ was measured after incubations, as a close approximation of total uptake. In order to retain comparability, all results in this paper refer to ${ }^{14} \mathrm{CO}_{2}$ measurements unless otherwise stated.

\section{Urea uptake kinetics}

Kinetic experiments showed that uptake closely followed Michaelis-Menten kinetics, and the saturation level was reached with added urea concentrations in the order of 15 to $20 \mu \mathrm{g} \mathrm{N} \mathrm{I}{ }^{-1}$ (e.g. Fig 2C). When the absolute urea uptake rate was calculated by multiplying turnover rates $(1 / T)$ with the sum of chemically analyzed and added urea concentrations, a decreasing curve over increasing urea additions was obtained (Fig. 1).

This kind of curve is usually interpreted as an indication of erroneously high results from nutrient analy-

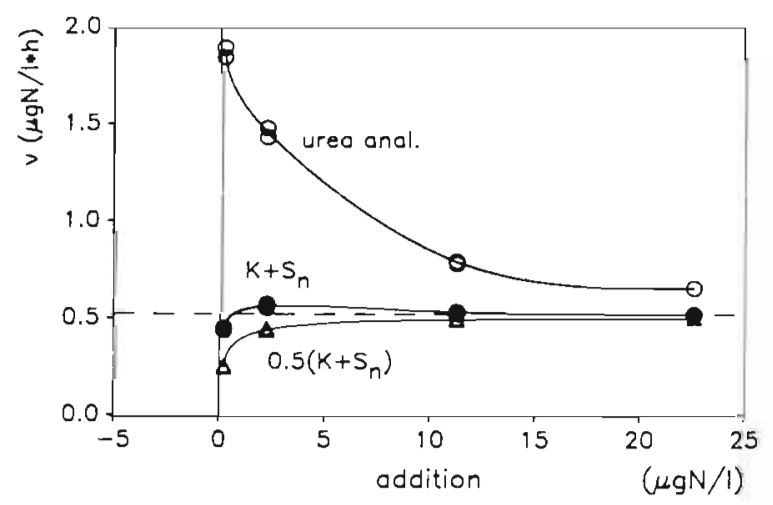

Fig. 1. Urea uptake rate $\left[\mathrm{v}=\left(S_{\mathrm{n}}+A\right) / T\right]$, calculated with chemically analyzed urea concentration, kinetic sum $\left(K+S_{n}\right)$, and $0.5\left(K+S_{n}\right)$ as estimates for ambient urea concentration $\left(S_{n}\right)$. Dashed line denotes kinetic maximum uptake velocity $\left(V_{\max }\right)$
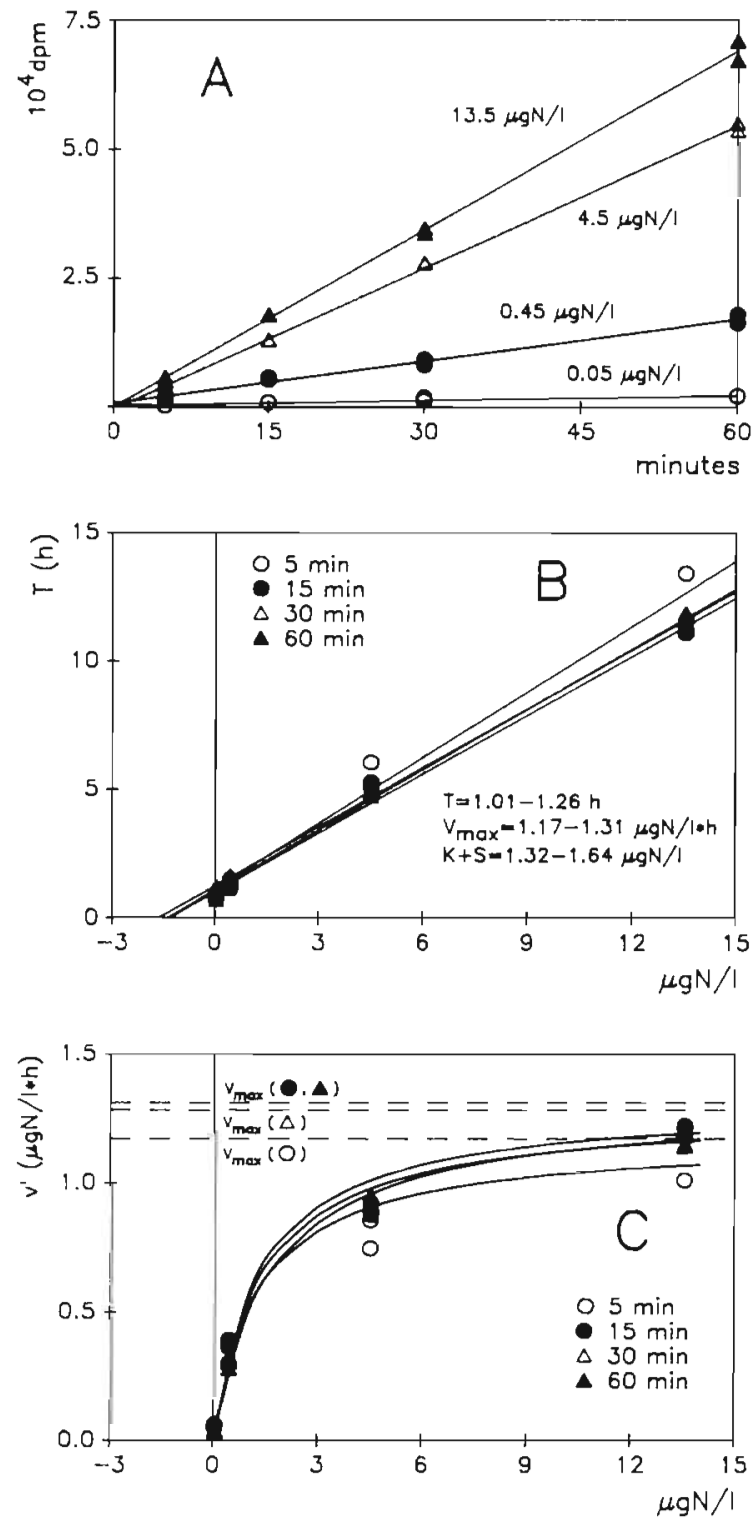

Fig. 2. Urea uptake kinetics during a time series experiment, 1 July 1988. (A) Uptake (dpm) during the experiment at dif.ferent added concentrations. (B) Turnover time $(T$ ) vs urea addition (A) with different incubation times. (C) Uptake rate $\left(v^{\prime}=A / T\right)$ vs urea addition $(A)$ with different incubation times. Dashed lines denote respective kinetic maximum uptake velocities $\left(V_{\max }\right)$

sis (e.g Eppley et al. 1977), and the phenomenon was observed with urea uptake measurements by Eppley et al. (1977) and Sahlsten et al. (1988). If the kinetic $K+S_{n}$ value, or a fraction of it as an approximation of $S_{n}$ was used instead of urea concentration from the chemical analysis, a more realistic curve was obtained (Fig. 1).

A short-term time series of urea uptake kinetics was measured in order to reveal possible enhanced or 

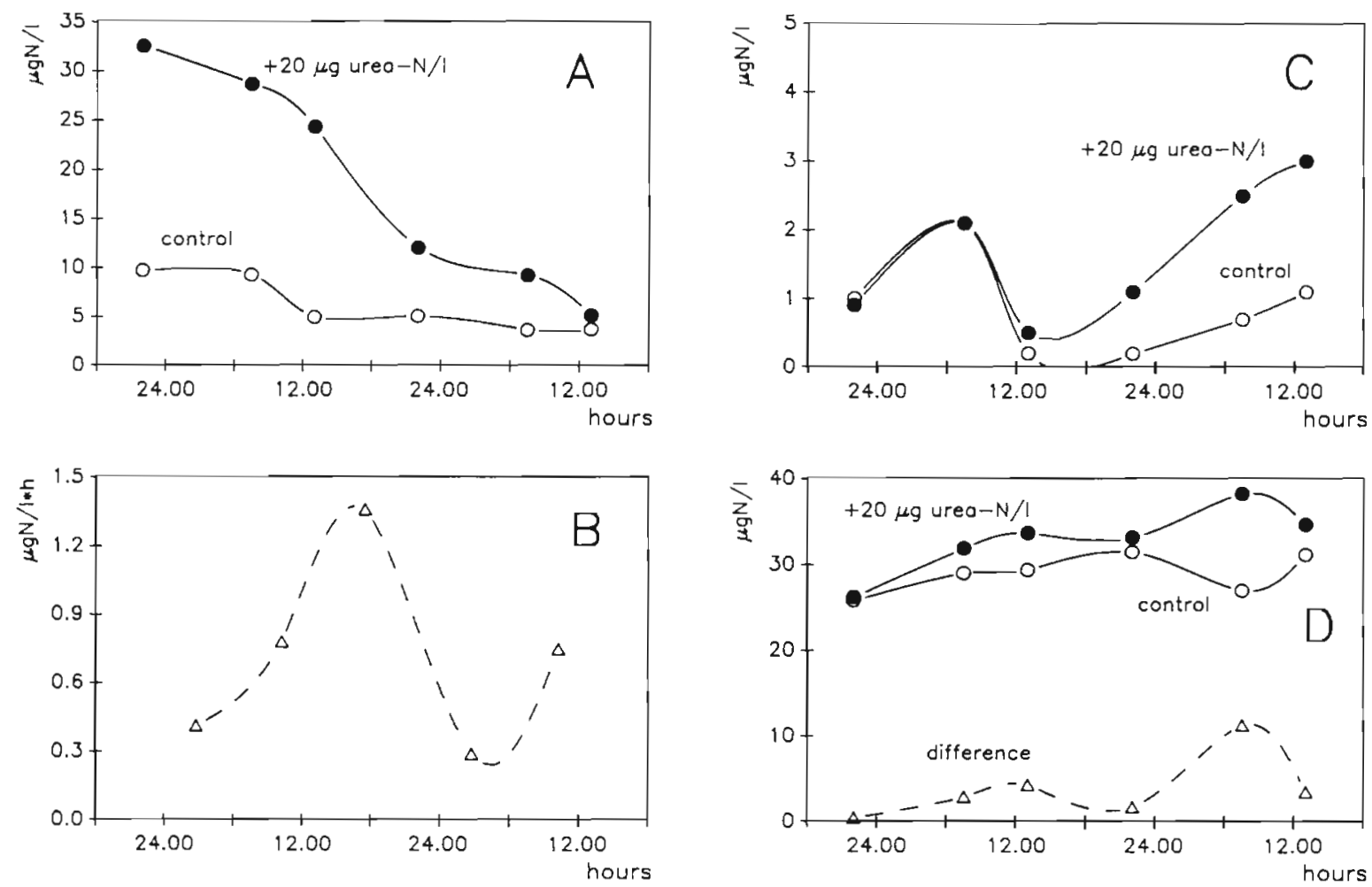

Fig. 3. Experiment on nonlabelled urea depletion, 28 to 30 June 1988. (A) Urea concentrations in the control and urea addition units. (B) Urea depletion $(v=d S / d t)$ in the urea addition unit, plotted in the midpoints of successive sampling times. (C) Ammonium concentration in the control and urea addition units. (D) Particulate organic nitrogen concentration in the control and urea addition units. Dashed curve denotes the difference between the units

surge uptake of urea immediately after substrate addition. Conway \& Harrison (1977), McCarthy \& Goldman (1979) and Glibert \& Goldman (1981) have presented evidence for this phenomenon in ammonium uptake, and Horrigan \& McCarthy (1981) found that the length of the incubation period affected the observed $V_{\max }$ for urea uptake in cultures.

However, our results did not support this in urea uptake of natural phytoplankton, as it remained quantitatively and qualitatively constant during the experiment (Fig. 2). Uptake was completely linear over time with all added concentrations (Fig. 2A), and the kinetic properties remained essentially unaltered (Fig. 2B, C).

The kinetic parameters describing urea uptake in the light varied from 0.52 to $1.31 \mu \mathrm{g} \mathrm{N} \mathrm{l}^{-1} \mathrm{~h}^{-1}\left(V_{\max }\right)$, 1.01 to $3.41 \mathrm{~h}(T)$, and 0.97 to $1.84 \mu \mathrm{g} \mathrm{N}^{-1}\left(K+S_{n}\right)$, and they showed a clear succession during the experimental period. With the warming of the surface layer (from 16 to $22.5^{\circ} \mathrm{C}$ ), turnover times decreased and maximum uptake rates increased. The turnover times correspond to turnover rate $(1 / T)$ values of 29 to $99 \% \mathrm{~h}^{-1}$. Uptake in the dark was 60 to $85 \%$ of that in the light, in close agreement with the results of Kristiansen \& Lund (1989).

\section{Urea depletion rate}

Urea addition ( $20 \mu \mathrm{g} \mathrm{N}^{-1}$ ) in the experiment on nonlabelled urea depletion rate (Expt 4) was chosen on the basis of the kinetic data, in order to start the experiment from the saturation level with maximum urea uptake rate.

Fig. 3A \& B shows that the depletion rate had a clear diurnal pattern: during nighttime, it showed the lowest values, and a distinct peak was found in the afternoon. $\mathrm{NH}_{4}$ accumulation in the unit with urea addition started only after the first light period, and it did not exceed $10 \%$ of the original urea addition (Fig. 3C).

The accumulation of particulate organic nitrogen in the urea-enriched unit appeared more slowly than urea was depleted, as was the case with $\mathrm{NH}_{4}$ accumulation (Fig. 3D). In the beginning of the second light period, the depleted urea nitrogen (14.4 $\mu \mathrm{g} \mathrm{N}^{-1}$ )

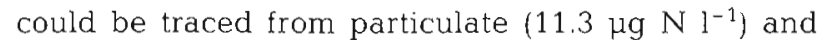

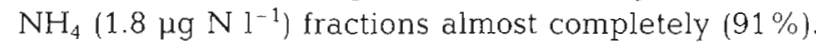
However, these fractions covered less than $30 \%$ of the depleted urea at the end of the experiment.

The highest depletion rate for urea in this experi-

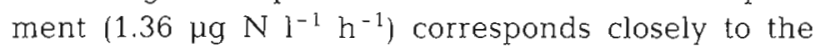


maximum uptake rates observed in kinetic experiments.

\section{Enrichment studies: immediate effects}

The incubations in the first enrichment experiment were performed immediately after prefractionations and nutrient additions according to Table 1 . The results are shown in Fig. 4 for urea turnover rate, pri-
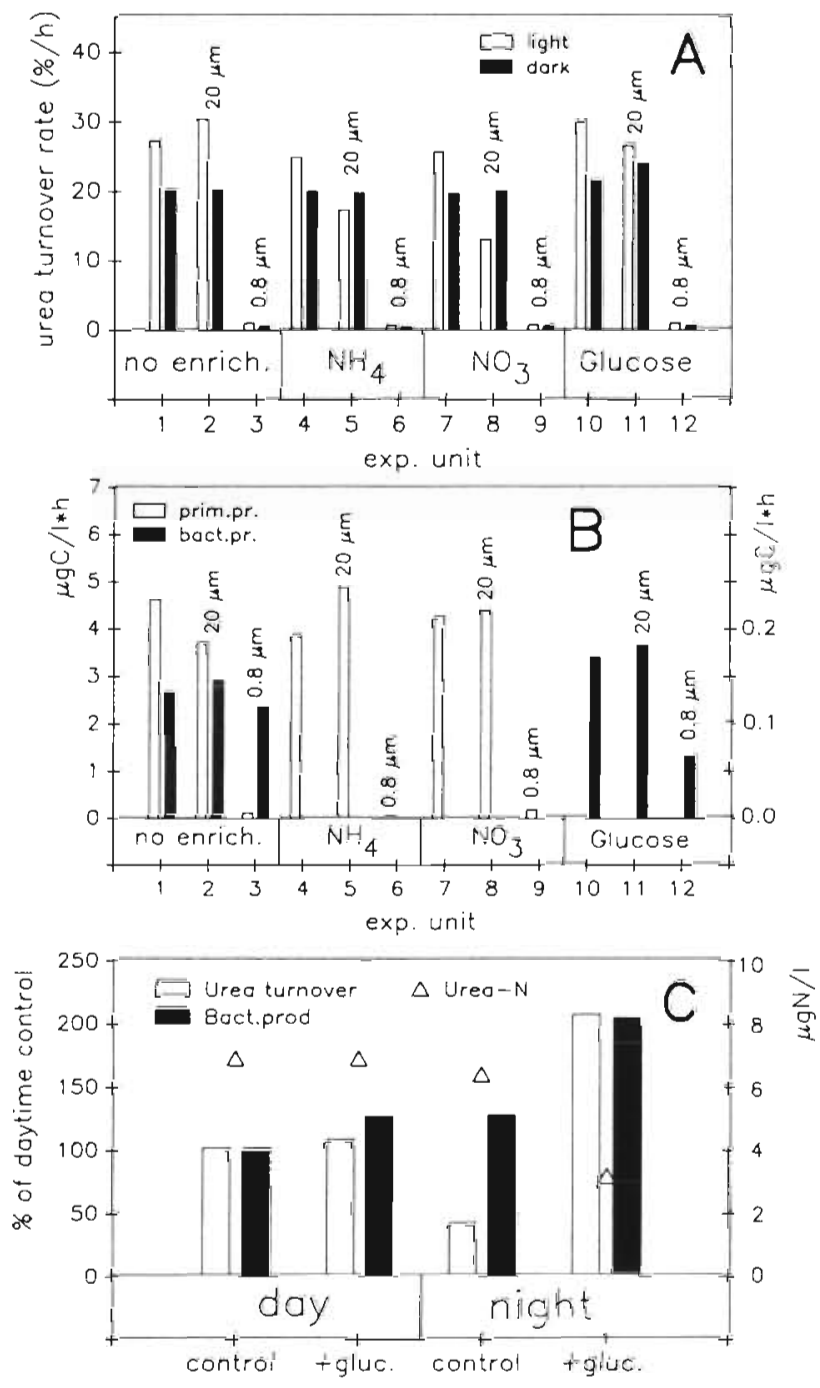

Fig. 4. Experiment on effects of nutrient additions in different size fractions, 22 June 1988 (see Table 1). (A) Urea turnover rate $(1 / T)$ in the light and in the dark. (B) Primary productivity (left $y$-axis) and bacterial productivity (right $y$-axis). Primary productivity was measured from Units 1 to 9 , bacterial productivity from Units 1 to 3 and 10 to 12. (C) Urea turnover rate $(1 / T)$ and bacterial productivity in the control and glucose addition units, immediately (day) and $12 \mathrm{~h}$ after (night) nutrient addition, expressed as \% of daytime control. Respective urea concentrations in $\mathrm{mg} \mathrm{N}^{-1}$ mary and bacterial productivity. The $20 \mu \mathrm{m}$ prefiltration did not diminish primary productivity systematically, but only a negligible amount of primary productivity was measured from the $0.8 \mu \mathrm{m}$ filtrate (Fig. $4 \mathrm{~B}$ ). Roughly the same size-distribution pattern was found with urea turnover rate (Fig. 4A), in contrast to bacterial productivity, of which a significant fraction was found to pass $0.8 \mu \mathrm{m}$ (Fig. 4B). These results clearly indicate that phytoplankton was dominating urea uptake.

None of these rate measurements showed a straightforward immediate stimulation or inhibition due to nutrient additions. Urea turnover rate measurements in the dark (Fig. 4A) were uniform in all experimental units except for a slight increase in the glucose addition units. In these units, bacterial productivity was also somewhat elevated (Fig. 4B).

The parallel incubations in the light showed generally faster urea turnover rates than in the dark (Fig. 4A), as in the kinetic experiments, with the exception of prefractionated $(<20 \mu \mathrm{m})$ units with inorganic nitrogen additions. Here the urea turnover rates were lower than either in parallel nonfractionated or dark incubations.

After $12 \mathrm{~h}$, at midnight, urea turnover rate and bacterial productivity were measured from the control and glucose addition units (Fig. $4 \mathrm{C}$ ). In accordance with the diurnal cycle observed in the urea depletion experiment (Fig. 3B), urea tumover rate at night was $40 \%$ of the daytime measurement in the control unit. In the glucose addition unit, urea turnover rate was over $200 \%$ of the daytime control, as was the case with bacterial productivity (Fig, $4 \mathrm{C}$ ). In this unit urea concentration had also clearly decreased compared to other units (Fig. 4C). These results suggest that the addition of organic carbon source had stimulated bacterial uptake of urea.

\section{Enrichment studies: effects after overnight delay}

In Expt 2, the effects of nutrient additions were studied after an overnight delay (Table 2). Inorganic nutrients $\left(\mathrm{NH}_{4}, \mathrm{PO}_{4}\right)$ had been depleted in the units with combined additions, but in the units with single $N$ or $P$ additions, the concentrations were still higher than ambient levels (Fig. 5A). Urea concentrations had again decreased in the units with organic carbon additions (Fig. 5A).

Inorganic nutrient additions, especially when combined, had clearly stimulated phytoplankton. This could be seen both in chl a and primary productivity (Fig. 5B). The combined addition of $\mathrm{PO}_{4}$ and organic carbon stimulated bacterial productivity (Fig. 5B).

Urea turnover rate showed a pattern which clearly differed from both primary and bacterial productivity 

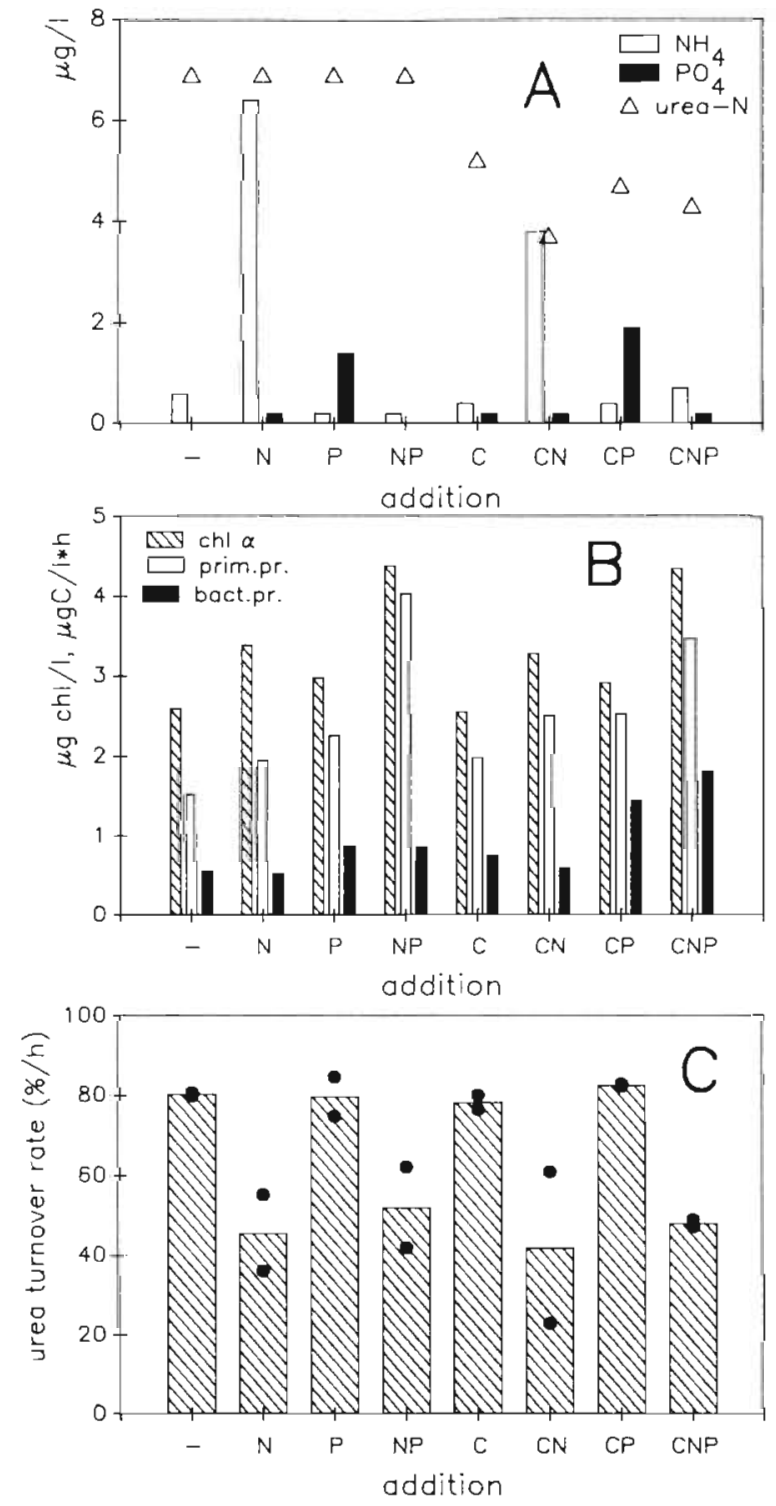

Fig. 5. Experiment on delayed effects of nutrient additions, 27 to 28 June 1988 (see Table 2). $\mathrm{N}=20 \mathrm{mg} \mathrm{NH}_{4}-\mathrm{N}^{-1}, \mathrm{P}=5 \mathrm{mg}$ $\mathrm{PO}_{4}-\mathrm{P}^{-1}, \mathrm{C}=50 \mathrm{mg}$ glucose-C $\mathrm{l}^{-1}$. (A) Nutrient concentrations at the start of incubations. (B) Chlorophyll $a_{\text {, primary }}$ and bacterial productivity. (C) Urea turnover rate $(1 / T)$. Circles: replicates, bars: averages

measurements, as it had systematically decreased in the units with $\mathrm{NH}_{4}$ additions (Fig. 5C).

The prefractionation results from this experiment showed that phytoplankton production was dominated by smallest nanoplankton or picoplankton, as 50 to $75 \%$ of primary productivity passed $3 \mu \mathrm{m}$ prefiltration. Less than $10 \%$ passed $0.8 \mu \mathrm{m}$ (Fig. $6 \mathrm{~A}$ ). With bacterial productivity, over $60 \%$ passed $3 \mu \mathrm{m}$, and 20 to $50 \%$ was found below $0.8 \mathrm{\mu m}$ (Fig. 6B).

The urea turnover rate derived from the prefractionated samples produced controversial results in this
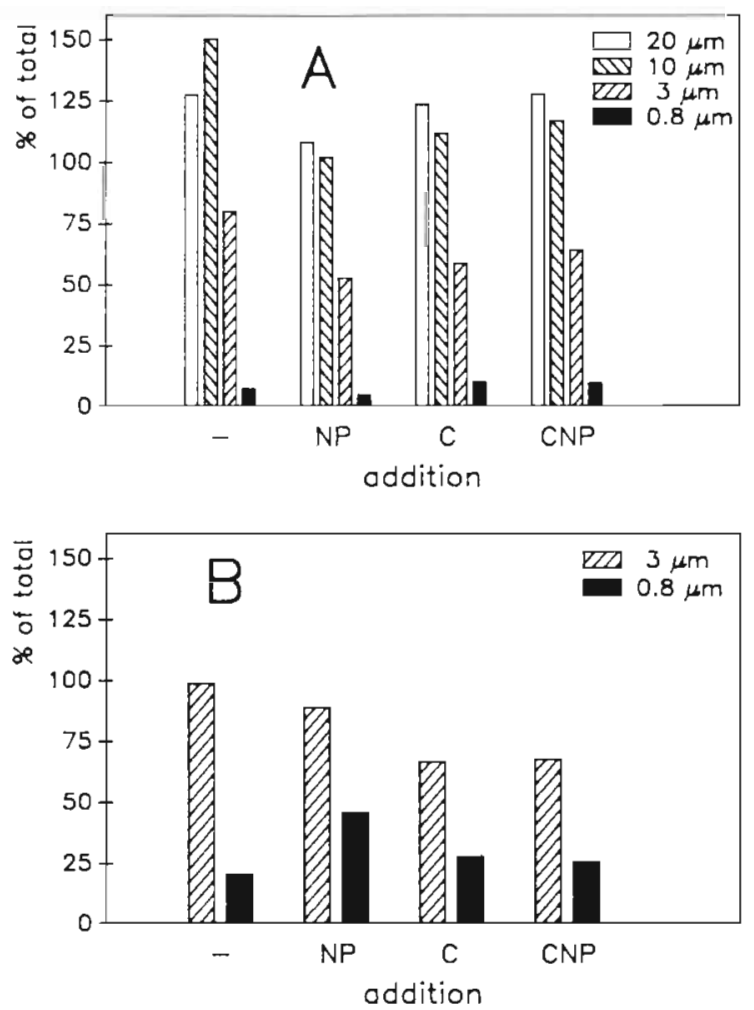

Fig. 6. Primary and bacterial productivity in prefractionated incubations in Expt 2, 28 June 1988 (see Table 2)

experiment (data not shown). In 3 out of 4 units, all prefractionations drastically reduced urea turnover rate. In the unit with all nutrient additions, the pattern was different and comparable to prefractionation results from Expt 1 (Fig. 4A). These results indicate again that phytoplankton was responsible for urea uptake.

The reduction of urea turnover rate after other prefractionations is difficult to explain satisfactorily, as both primary and bacterial productivity incubations were performed from the same filtrates and no corresponding reductions were found (Fig. 6A, B). This seems to rule out the possibility of some maltreatment of the organisms during the prefiltrations. It is possible that prefractionation had damaged fragile zooplankton thus affecting urea concentrations in the filtrate.

\section{Enrichment studies: effects after $24 \mathrm{~h}$ delay}

In Expt 3, the effects of inorganic nutrient additions were measured after a $24 \mathrm{~h}$ delay. Emphasis was laid on $\mathrm{NH}_{4}$ inhibition of urea uptake on several $\mathrm{NH}_{4}$ addition levels (Table 3). After $24 \mathrm{~h}$, only the units with

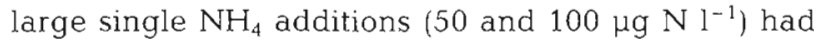
clearly elevated $\mathrm{NH}_{4}$ concentrations left (10.9 and $60.2 \mu \mathrm{g} \mathrm{N} \mathrm{l}^{-1}$ ), and the depletion rates of $\mathrm{NH}_{4}$ in these 


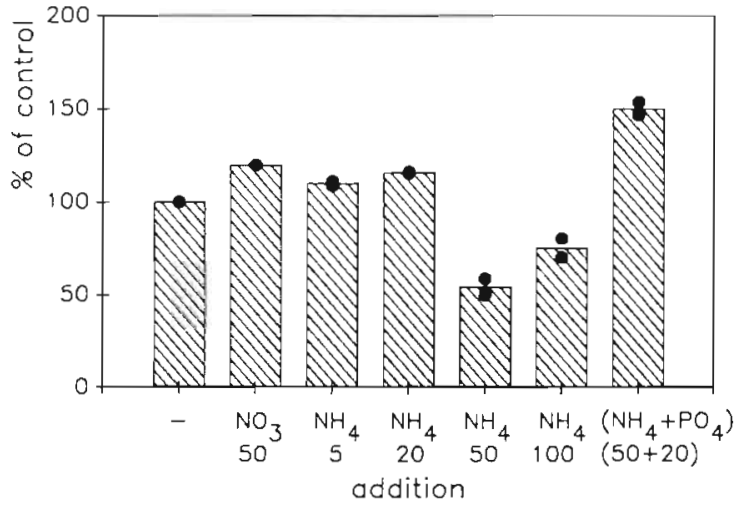

Fig. 7. Urea turnover rate $(1 / T)$ in the experiment on delayed effects of nutrient additions, 30 June to 1 July 1988 (see Table 3). expressed as \% of control unit. Circles: replicates, bars: averages

units were 1.50 and $1.53 \mu \mathrm{g} \mathrm{N} \mathrm{I}^{-1} \mathrm{~h}^{-1}$, respectively. In the unit with the combined addition of $\mathrm{PO}_{4}$ and $50 \mathrm{\mu g}$ $\mathrm{N}^{-1}$ of $\mathrm{NH}_{4}$, the depletion rate for $\mathrm{NH}_{4}$ was $1.83 \mu \mathrm{g} \mathrm{N}$ $\mathrm{l}^{-1} \mathrm{~h}^{-1}$

Urea turnover rate results showed clearly the inhibition by $\mathrm{NH}_{4}$ additions in the units where $\mathrm{NH}_{4}$ concentrations were still elevated (Fig. 7). The corresponding $\mathrm{NO}_{3}$ addition $\left(50 \mu \mathrm{g} \mathrm{N}^{-1}\right)$ did not cause inhibition of urea tumover rate, although a $\mathrm{NO}_{3}$ concentration of $19.5 \mu \mathrm{g} \mathrm{N}^{-1}$ was left at the time of the incubation. The depletion rate for $\mathrm{NO}_{3}$ was $1.20 \mathrm{\mu g} \mathrm{N} \mathrm{I}^{-1} \mathrm{~h}^{-1}$. The unit with the combined $\mathrm{PO}_{4}$ and $\mathrm{NH}_{4}$ addition showed the highest urea turnover rate, over $150 \%$ of control (Fig. 7).

\section{DISCUSSION}

\section{Respiration and particulate uptake of ${ }^{14} \mathrm{C}$-urea}

We found a uniformly high respiration percentage (98 to $99 \%$ ) after ${ }^{14} \mathrm{C}$-urea incubations in a variety of experiments. This result is identical to the observations from cultured phytoplankton by Carpenter et al. (1972) and Horrigan \& McCarthy (1981), but contradicts several other results both from culture and natural phytoplankton studies.

Mitamura \& Saijo (1986) and Mitamura (1986a, b) reported in their studies on lacustrine phytoplankton that the percentage showed diumal variation, the particulate percentage being 11 to $47 \%$ during daytime. From a coastal area, Mitamura \& Saijo (1975) reported particulate uptake percentages of 38 to $84 \%$ in light incubations. Price \& Harrison (1988) noted that in their short-term time series incubations with Thalassiosira pseudonana the particulate percentage was $63 \%$ dur- ing the first minutes, whereafter it decreased down to approximately $20 \%$ as estimated from their Fig. 3. Both Mitamura \& Saijo (1986) and Price \& Harrison (1988) suggested a 2-phase model for ${ }^{14} \mathrm{C}$-urea uptake on the basis of these results.

We suspect that a methodological artifact is at least partly responsible for the higher particulate ${ }^{14} \mathrm{C}$ percentages referred to above. Both in the experiments by Horrigan \& McCarthy (1981) and in this study, the respired fraction was trapped immediately after incubations from closed incubation bottles, leading to respiration percentages of 98 to $99 \%$.

The studies which report higher particulate percentages (Mitamura \& Saijo 1975, 1986, Mitamura 1986a, b, Price \& Harrison 1988) have utilized a procedure where filtration is performed first, and the respired fraction is trapped thereafter from the filtrate. If respired ${ }^{14} \mathrm{CO}_{2}$ is not collected directly from closed incubation bottles, a significant part of it will obviously be lost, especially during the efficient aeration which is inevitable when filtrating the sample. In fact, Price \& Harrison (1988) noted a discrepancy between their ${ }^{14} \mathrm{C}$-urea uptake rates and the disappearance of urea in their experiments, and proposed '... that some of the ${ }^{14} \mathrm{C}$ is lost to a compartment not included in our analysis.' They hypothesized a dissolved organic ${ }^{14} \mathrm{C}$ loss during the incubations, but an alternative explanation could be incomplete trapping of the respired ${ }^{14} \mathrm{CO}_{2}$.

A possible cause for higher particulate ${ }^{14} \mathrm{C}$ percentages in the light than in the dark is naturally reassimilation of respired ${ }^{14} \mathrm{CO}_{2}$ in photosynthesis. This artifact has been found insignificant because of rapid dilution of ${ }^{14} \mathrm{CO}_{2}$ in the medium of marine phytoplankton cultures (Horrigan \& McCarthy 1981), but in lakes it could be a more serious source of error than with marine phytoplankton because of far lower $\mathrm{CO}_{2}$ background levels.

\section{Chemical and kinetic urea analyses}

The kinetic maximum uptake rates, obtained with ${ }^{14} \mathrm{C}$-urea, and the depletion rate of urea, obtained with chemical analyses (diacetyl monoxime method), fit together quite well (range for kinetic values 0.5 to $1.3 \mu \mathrm{g}$ $\mathrm{N}^{-1} \mathrm{~h}^{-1}$, for chemical daytime values 0.8 to $1.3 \mu \mathrm{g} \mathrm{N} \mathrm{l^{-1 }}$ $\mathrm{h}^{-1}$; see Figs. 1 to 3 ). However, a considerable discrepancy between the kinetic $K+S_{n}$ value and chemical urea analyses was consistent, the latter being several times higher than the concentration sum $K+S_{\mathrm{n}}$. This sum should be composed of the ambient substrate concentration $\left(S_{n}\right)$ and the half-saturation constant $K$, describing the affinity of the community for the substrate.

This kind of result is rather common in uptake studies with radioactive organic substrates (glucose, amino 
acids, urea, etc.), $\mathrm{PO}_{4}$ and inorganic nitrogen compounds (e.g. Gocke et al. 1981, Kristiansen \& Lund 1989), and it is often explained by introducing the concept of 'biologically available' substrate in question. Chemical analyses often involve drastic manipulations of the sample (e.g. pH), which can bring some absorbed, chelated, biologically loosely bound etc. compartments into solution. Therefore, chemical analyses easily overestimate the 'biologically available' (that is, truly dissolved) compartment of the substrate, while the kinetic analysis is based on the biologically available substrate during the incubation.

This explanation seems valid also for the abovementioned results: if the chemical analyses systematically overestimate the prevailing dissolved urea concentration because of sample manipulation, the kinetic concentration sum $\left(K+S_{\mathrm{n}}\right)$ should be consistently smaller than measured urea concentration, as it was. However, this artificially increased background should not affect the depletion rate calculations, as they are based on the differences between successive chemical analyses - the background is counted out. Therefore the kinetic and chemical results agree in this case.

Another indication of overestimated urea concentrations in chemical analysis was the nonsense curve which was produced when chemically analyzed urea concentration was included in urea uptake rate calculations (Fig. 1).

\section{The fate of urea $\mathbf{N}$}

Urease or a corresponding enzymatic system for urea degradation is considered to be intracellular in phytoplankton (Berns et al. 1966, Leftley \& Syrett 1973). If urea is degraded within the cell, the rapid (practically immediate) and almost complete liberation of ${ }^{14} \mathrm{C}$ as ${ }^{14} \mathrm{CO}_{2}$ after urea uptake indicates that enzymatic uptake through the cell membrane is closely coupled to enzymatic degradation of urea within the cell. Therefore, intracellular storage pools of urea seem to be nonexistent or at least quantitatively nonsignificant. Wheeler et al. (1982) have presented evidence for a similar pattern in $\mathrm{NH}_{4}$ assimilation, where uptake through the cell membrane would be directly related to $\mathrm{NH}_{4}-\mathrm{N}$ utilization in macromolecule synthesis.

Price \& Harrison (1988) proposed an urea uptake model for Thalassiosira pseudonana which included efflux of both urea, and $\mathrm{NH}_{3}$ after urea degradation, followed by reabsorption to a varying degree. They also refer to 'evidence that in the ocean much of the urea $\mathrm{N}$ taken up is not retained by phytoplankton and over the short term is not reabsorbed'. This evidence is based on observed discrepancies between ${ }^{15} \mathrm{~N}$ and ${ }^{14} \mathrm{C}$ urea assimilation patterns in short-term incubations.
We have already suspected that this discrepancy may at least partly arise from methodological sources.

In Expt 4, $\mathrm{NH}_{4}$ accumulation was followed during urea depletion. A small but significant difference in $\mathrm{NH}_{4}$ concentrations developed between the control and urea addition units (Fig. 3C), with a time lag from the peak of urea depletion (Fig. 3B). At the end of the experiment when all added urea had been taken up, a maximum of $10 \%$ of the urea $\mathrm{N}$ enrichment was found as $\mathrm{NH}_{4}-\mathrm{N}$ in the medium, in accordance with the urea depletion experiments by Eppley et al. (1971).

It seems therefore that after urea molecules are transported through the cell membrane, they are immediately degraded into $\mathrm{NH}_{3}$ and $\mathrm{CO}_{2}$, a major part of the produced $\mathrm{NH}_{3}$ is retained by the cells and $\mathrm{CO}_{2}$ is liberated in the medium. Our results thus indicate that urea was a genuine nitrogen source for phytoplankton, in contrast to the urea uptake model by Price \& Harrison (1988).

\section{N source preferences}

Since Dugdale \& Goering (1967) introduced the concepts of new and regenerated planktonic production, the relative uptake preferences of the major nitrogen sources for the planktonic community have been extensively studied by comparing in situ uptake rates and concentrations of $\mathrm{NH}_{4}, \mathrm{NO}_{3}$ and urea (e.g. the Relative Preference Index, RPI, of McCarthy et al. 1977).

Widely different mechanisms control the availability of new and regenerated nitrogen sources. For nitrate, spatially extensive physical transport or accumulation over long periods of time are most important, while immediate regeneration within the planktonic food web governs ammonium and urea availability. It is therefore doubtful whether ambient concentrations could represent actual relative availability of the $N$ sources. Experimental manipulation of availability appears thus essential for preference evaluations (Tamminen 1995).

In our experiments, $\mathrm{NO}_{3}$ did not suppress urea turnover (Figs. 4A \& 7). The experiments also showed the transient nature of $\mathrm{NH}_{4}$ suppression on urea turnover rate. Immediately (0 to $2 \mathrm{~h}$ ) after the $\mathrm{NH}_{4}$ addition, no suppression of urea uptake was observed in unfractionated experimental units (Fig. 4A).

With a time lag of $20 \mathrm{~h}$ from enrichments, urea turnover rate had decreased in the experimental units which had received $\mathrm{NH}_{4}$ (Fig. 5C), no matter whether traces of the addition were present or not at the start of the incubation (Fig 5A). After 24 h, urea turnover rate had recovered in the units where $\mathrm{NH}_{4}$ had been depleted, but clear suppression was observed if traces 
of the additions were still present (Fig. 7), in accordance with the $\mathrm{NH}_{4}$ inhibition results presented by Kokkinakis \& Wheeler (1988).

The depletion rates for each nitrogen source, when they were added alone, were rather similar $(1.20,1.36$,

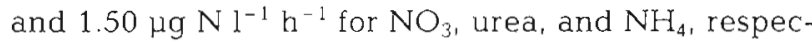
tively). This suggests that nitrogen sources were interchangeable to a high degree, and uptake of each source was regulated mainly by availability, and only secondarily by preference. Although this might not necessarily be the case for any single phytoplankton species, for the community as a whole it seems obvious. However, Horrigan \& McCarthy (1981) presented evidence for similar lack of preference between nitrogen sources in diatom cultures as well.

When $\mathrm{PO}_{4}$ was also added in the experiments, nitrogen sources were utilized clearly more efficiently: $\mathrm{NH}_{4}$ depletion rate increased in Expts 2 and 3 (Fig. 5A), and urea turnover rate increased in Expt 3 (Fig. 7). Moreover, organic carbon addition stimulated bacterioplankton production, and obviously also bacterial utilization of urea (Fig. 4C), which was otherwise almost negligible. Kirchman et el. (1990) have presented analogous evidence for organic $C$ limitation of bacterial $\mathrm{NH}_{4}$ uptake.

These nutrient uptake results indicate that the planktonic community was in a state of multiple substrate limitation, phytoplankton by nitrogen and phosphorus, and bacterioplankton by carbon and phosphorus. This is supported by the primary productivity, chl a and bacterial productivity responses in multiple enrichment assays (Fig. 5B).

Hierarchical regulation of nitrogen uptake thus seemed to operate during the research period: (1) the availability of other growth factors (for phytoplankton, mainly phosphate) defined the nitrogen need in cellular metabolism; (2) the availability of different forms of nitrogen governed the pick of choice in uptake; (3) if several alternative nitrogen sources were available, the preference of reduced forms of nitrogen according to the order $\mathrm{NH}_{4}>$ urea $>\mathrm{NO}_{3}$ seemed to prevail.

Under natural marine conditions, when nitrogen often is the primary limiting nutrient, and when nutrients are scarce compared to uptake saturation levels and thus not freely selected upon (that is, there is no room for the third-level regulation to occur), the commonly used preference measures (e.g. RPI; McCarthy et al. 1977) probably mainly reflect the relative availability of nitrogenous nutrients, not preference by phytoplankton in any physiological sense. During regenerated production periods, the relative proportions of $\mathrm{NH}_{4}$ and urea in remineralization might thus be the underlying cause behind observed apparent preferences in uptake of alternative nitrogen sources.
Acknowledgements. This study was carried out at the Tvärminne Zoological Station, University of Helsinki. Finland, as a contribution to the project PELAG on behalf of T Tamminen. The exchange program between the Academy of Finland and the Academy of Sciences of the German Democratic Republic enabled the collaboration.

\section{LITERATURE CITED}

Antia NJ, Berland BR, Bonin DJ, Maestrini SM (1975) Comparative evaluation of certain organic and inorganic sources of nitrogen for phototrophic growth of marine microalgae. J mar biol Ass UK 55:51.9-539

Berns DS, Holohan P. Scott E (1966) Urease activity in bluegreen algae. Science 152:1077-1078

Carpenter EJ, Remsen CC, Watson SW (1972) Utilization of urea by some marine phytoplankters. Limnol Oceanogr $17: 265-269$

Conway HL, Harrison PJ (1977) Marine diatoms grown in chemostats under silicate or ammonium limitation. IV. Transient response of Chaetoceros debilis, Skeletonema costatum, and Thalassiosira gravida to a single addition of the limiting nutrient. Mar Biol 43:33-43

Dugdale RC, Goering JJ (1967) Uptake of new and regenerated forms of nitrogen in primary productivity. Limnol Oceanogr 12:196-206

Eppley RW, Carlucci AF, Holm-Hansen O, Kiefer D, McCarthy JJ, Venrick E, Williams PM (1971) Phytoplankton growth and composition in shipboard cultures supplied with nitrate, ammonium or urea as the nitrogen source. Limnol Oceanogr 16:741-751

Eppley RW, Renger EH, Venrick EL, Mullin MM (1973) A study of plankton dynamics and nutrient cycling in the central gyre of the North Pacific Ocean. Limnol Oceanogr 18:534-551

Eppley RW, Sharp JH, Renger EH, Perry MJ, Harrison WG (1977) Nitrogen assimilation by phytoplankton and other microorganisms in the surface waters of the Central North Pacific Ocean. Mar Biol 39:111-120

Fuhrman JA, Azam F (1980) Bacterioplankton secondary production estimates for coastal waters of Britush Columbia, Antarctica, and California. Appl environ Microbiol 39 $1085-1095$

Fuhrman JA, Azam F (1982) Thymidine incorporation as a measure of heterotrophic bacterioplankton production in marine surface waters: evaluation and field results. Mar Biol 66:109-120

Furnas MJ, Smayda TJ, Deason EA (1986) Nitrogen dynamics in lower Narragansett Bay. II. Phytoplankton uptake, depletion rates of nitrogenous nutrient pools, and estimates of ecosystem remineralization. J Plankton Res 8: $755-769$

Glibert PM, Goldman JC (1981) Rapid ammonium uptake by marine phytoplankton. Mar Biol Lett 2:25-31

Gocke K, Dawson R, Liebezeit G (1.981) Availability of dissolved free glucose to heterotrophic micro-organisms. Mar Biol 62:209-216

Grasshoff K (1976) Methods of seawater analysis. Verlag Chemı, Weinheim

Harvey WA, Caperon J (1976) The rate of utilization of urea, ammonium, and nitrate by natural populations of manne phytoplankton in a eutrophic environment. Pacif Sci 30 : $329-340$

Horrigan SG, McCarthy Jf (1981) Urea uptake by phytoplankton at various stages of nutrient depletion. J Plankton Res 3:403-414 
Johnson KS, Petty RL (1983) Determination of nitrate and nitrite in sea water by flow-injection analysis. Limnol Oceanogr 28:1260-1266

Kanda J, Saino T, Hattori A (1985) Nitrogen uptake by natural populations of phytoplankton and primary production in the Pacific Ocean: regional variability of uptake capacity Limnol Oceanogr 30:987-999

Kirchman DL, Keil RG, Wheeler PA (1990) Carbon limitation of ammonium uptake by heterotrophic bacteria in the subarctic Pacific. Limnol Oceanogr 35:1258-1266

Kokkinakis SA, Wheeler PA (1988) Uptake of ammonium and urea in the northeast Pacific: comparison between netplankton and nanoplankton. Mar Ecol Prog Ser 43: $113-124$

Kristiansen S (1983) Urea as a nitrogen source for the phytoplankton in the Oslofjord. Mar Biol 74:17-24

Kristiansen S, Lund BA (1989) Nitrogen cycling in the Barents Sea - I. Uptake of nitrogen in the water column. Deep Sea Res 36:255-268

Kuparinen J, Lahti K, Talsi T, Tamminen T, Virtanen A (1984) Determination of the Michaelis-Menten kinetic parameters with single concentration assays. Publ Wat Res Inst, National Board of Waters, Finland 56:26-34

Kuparinen J, Uusi-Rauva A (1980) A simplified method to measure respiration rates of aerobic heterotrophic populations. Hydrobiologia 75:113-115

Leftley JW, Syrett PJ (1973) Urease and ATP: urea amidolyase activity in unicellular algae. J gen Microbiol 77:109-115

McCarthy JJ (1972) The uptake of urea by natural populations of marine phytoplankton. Limnol Oceanogr 17: $738-748$

McCarthy JJ, Goldman JC (1979) Nitrogenous nutrition of marine phytoplankton in nutrient-depleted waters. Science 203:670-673

McCarthy JJ, Rowland Taylor W. Taft JL (1977) Nitrogenous nutrition of the plankton in the Chesapeake Bay. 1. Nutrient availability and phytoplankton preferences. Limnol Oceanogr 22:996-1011

McCarthy JJ, Wynne D, Berman T (1982) The uptake of dissolved nitrogenous nutrients by lake Kinneret (Israel) microplankton. Limnol Oceanogr 27:673-680

Mitamura O (1986a) Urea metabolism and its significance in the nitrogen cycle in the euphotic layer of Lake Biwa. II.

This article was submitted to the editor
Half-saturation constant for nitrogen assimilation by fractionated phytoplankton in different trophic areas. Arch Hydrobiol 107:167-182

Mitamura $O$ (1986b) Urea metabolism and its significance in the nitrogen cycle in the euphotic layer of Lake Biwa. III Influence of the environmental parameters on the response of nitrogen assimilation. Arch Hydrobiol 107 281-299

Mitamura O, Saijo Y (1975) Decomposition of urea associated with photosynthesis of phytoplankton in coastal waters Mar Biol 30:67-72

Mitamura O, Saijo Y (1986) Urea metabolism and its significance in the nitrogen cycle in the euphotic layer of Lake Biwa. I. In situ measurement of nitrogen assimilation and urea decomposition. Arch Hydrobiol 107:23-51

Niemi M, Kuparinen J, Uusi-Rauva A, Korhonen K (1983) Preparation of ${ }^{14} \mathrm{C}$-labeled algal samples for liquid scintillation counting. Hydrobiologia 106:149-156

Paasche E, Kristiansen S (1982) Nitrogen nutrition of the phytoplankton in the Oslofjord. Estuar coast Shelf Sci 14 $237-249$

Price NM, Harrison PJ (1988) Uptake of urea C and urea N by the coastal marine diatom Thalassiosira pseudonana. Limnol Oceanogr 33:528-537

Sahlsten E, Sörensson F, Pettersson K (1988) Planktonic nitrogen uptake in the south-eastern Kattegat. J exp mar Biol Ecol 121:227-246

Steemann Nielsen E (1952) The use of radio-active carbon $\left({ }^{14} \mathrm{C}\right)$ for measuring organic production in the sea. J Cons int Explor Mer 18:117-140

Tamminen T (1995) Nitrate and ammonium depletion rates and preferences during a Baltic spring bloom. Mar Ecol Prog Ser 120:123-133

Wheeler PA, Glibert PM, McCarthy JJ (1982) Ammonium uptake and incorporation by Chesapeake Bay phytoplankton: short term uptake kinetics. Limnol Oceanogr 27 $1113-1128$

Wheeler PA, Kirchman DL (1986) Utilization of inorganic and organic nitrogen by bacteria in marine systems. Limnol Oceanogr 31:998-1009

Wright RT, Hobbie JE (1966) Use of glucose and acetate by bacteria and algae in aquatic ecosystems. Ecology 47 $447-464$

Manuscript first received: December 30, 1993

Revised version accepted: March 14, 1995 